\title{
E-Marketing via Social Networking and Its Role on the Enhancement of Small Business Projects
}

\author{
Najah Hassan Salamah ${ }^{1}$ \\ ${ }^{1}$ Department of Marketing, Faculty of Economic and Administration, King Abdul-Aziz University, Saudi Arabia \\ Corresponding: Najah Hassan Salamah, Department of Marketing, Faculty of Economic and Administration, \\ King Abdul-Aziz University, Saudi Arabia. E-mail: nsalamah@kau.edu.sa
}

Received: November 30, 2016 Accepted: December 15, $2016 \quad$ Online Published: January 16, 2017

doi:10.5539/ijms.v9n1p65 URL: http://dx.doi.org/10.5539/ijms.v9n1p65

\begin{abstract}
This study aimed to highlight the concepts of e-marketing through social networking sites and its role in the enhancement of small business projects; and the extent to which it is effective for proprietors of such projects. Questionnaire technique was used for collecting data from large number of individuals. Analysis of data was performed by using the analytic and descriptive approaches. The population was comprised of some directors of the small business projects in the Kingdom of Saudi Arabia. The study evaluated that there is a general recognition for the significance of using social networking sites in marketing. To advertise the products and services of the small business projects in consideration with social media sites as a modern method for e-marketing together with its widespread application, it is essential to utilize the need for taking advantage from the revolution of social networking sites in marketing sector. Doing so will give attention to creative activities related to the sorts of such small projects, and attempt to know continuously the latest electronic applications. The retrieved outcomes of the study demonstrate that how e-marketing and social networking sites support small business projects and identify the major obstacles faced by the proprietors in Saudi Arabia.
\end{abstract}

Keywords: e-marketing, social networking sites, small business projects, Kingdom of Saudi Arabia

\section{Introduction}

\subsection{Aims and Scope}

E-marketing is referred as digital marketing, in which the services and products are advertised digitally via Internet. The study has been conducted to highlight the role of social networking in the enhancement of small business projects via e-marketing. Moreover, the study has emphasized upon the awareness of use of digital technologies while marketing the services of small business. The study specifically contributed in the field of marketing and small businesses, as well as the marketing of social networking sites among Saudi Arabia.

\subsection{Problem Statement}

The problem of the study revolves around seeking the activities into e-marketing via social networking sites and their role in enhancing small business projects. The research process covers the difficulties faced by the owners of small business in the implementation of e-marketing activities. The problems limit the ability of the owners of small business projects in the Kingdom of Saudi Arabia to achieve the maximum possible benefit of applying e-marketing. The study is contributed to the small business projects and their enhancements via social networking sites, which will be of great importance in the future.

\subsection{Objectives}

The objectives of the study are given below:

1) Recognize the importance of e-marketing through the social networking sites for small business projects.

2) Identify the level of application of e-marketing in small business projects through the social networking sites.

3) Highlight the extent to which e-marketing is effective in encouraging the proprietors of small business projects to continue their task, and to maximize the benefit disseminated by the social networking sites.

4) Specify the difficulties faced by the proprietors of small business projects when they practice e-marketing 
through the social networking sites.

5) Identify the obstacles that hinder the success and prosperity of e-marketing in relation with the small business projects.

\subsection{Importance of Problem}

The research holds great significance due to certain factors that change incidents of contemporary projects from traditional marketing to internet marketing (or e-marketing). The remarkable increase in the role of electronic networking sites is a tangible phenomenon in marketing goods and services, and the lack of studies on identifying the impact of e-marketing on small business projects stimulate that the topic is somehow unique.

\subsection{Relevant Scholarly Articles}

The impact of transformation, which is currently witnessed across the globe in various fields due to the dissemination of digital technology, is not far from the marketing occupation. Marketing is considered as a necessary key for achieving the organization's objectives, which include specification of the needs of the consumers and satisfaction of clients in such a manner that is more effective and efficient than the competitors. E-marketing is helpful for saving huge costs, reducing risk ratio, and provision of golden opportunities that stimulate young people to engage in the process of practical life and commencement of their small business projects (Abu Radwan, 2006; Ali, 2007).

\subsection{Research Questions}

The research questions of the study are given below:

1) What is the role played by e-marketing through social networking sites in regards of small business projects?

2) What are the necessary foundations for the success of e-marketing through social networking sites?

3) What are the methods required for the enhancement of marketing the goods and services of small business projects via social networking sites?

\section{Literature Review}

Maysah Khallah (2003) posited to realize that to which extent the Saudi business organizations at the private sector practiced the e-commerce as an effective means for enhancing the organizations' marketing capabilities. The results of the study indicated that the overwhelming majority of participating organizations have websites on the Internet. Ali Al-Amir (2007) aimed to monitor the reality of e-commerce in the Kingdom of Saudi Arabia. The result indicated that the trend of internet users in Saudi Arabia depends on the difference in monthly income and the level of education.

Sharman \& Al-bwaanh (2011) sought to find out the guide of industrial enterprises in Jordan. The study also identified the importance of e-marketing and its effect on the quality of service. The result of the study indicated that there was a positive relationship existed between the profitability of the enterprise and the opening of new markets (Altai et al., 2009; Grahl, 2013).

\subsection{E-marketing}

The advancement in information systems is considered as a new qualitative leap that contributed to serve in different marketing activities. This advancement has given marketing personnel the opportunity to ponder over practicing the activities via Internet. These activities are commonly termed as e-marketing. The practice of marketing activities through Internet is considered as the mean for having an access to millions of potential customers all over the world that belong from different age brackets, culture and sex (Welson et al., 2011; Bear, 2013).

\subsection{Importance of E-marketing}

Since the early $90 \mathrm{~s}$, e-marketing has been increased astonishingly across the globe. It is essential that the importance of e-marketing must be realized, because it has a positive impact on the development of the economy. It necessitates to thoroughly consider the real situation of e-commerce, which still requires the adoption of legal security and safe customs procedures operations (Yousuf, 2006; Assiri, 2004).

\subsection{Importance of the Social Networking Sites in Marketing}

Since the inception of social media, the business organizations have faced various challenges regarding the customer satisfaction, stiff competition and target population. Thus, traditional selling and buying activities were failed to meet the needs of customer who were aspired to have a continuous contact with the business 
organizations (Kyle, 2010; Kelly et al., 2010).

The cluster of information provided on various social media sites has gained tremendous interest among people all over the world. Additionally, it is also helpful for reducing the risks and costs of marketing campaigns (Maisa, 2003; Member, 2013; Ghali, 2012).

\subsection{Most Important Obstacles of Marketing through Electronic Social Networking Sites}

The biggest challenges that confront by organizations via marketing through social networking sites include the shortage of time, lack of certainty and credibility, relative absence of security and privacy, and inadequacy of knowledge about the social networking sites (Mahmoud Abdel Samie, 2012, p. 19; Cao, 2013).

\subsection{Small Business Projects}

Small business projects are highly dedicated to meet the needs of local consumers, which are ultimately helpful in the development of economy. Additionally, such small projects benefit the community by creating job opportunities for citizens, and positively contribute in the reduction of unemployment. The government should fulfill the financing needs of proprietors and provide due training to staff so, that they can better represent their products locally, regionally and internationally (Al-Sharman, Ziad, \& Albwaanh, 2011).

\subsection{Ways for Supporting the Marketing of Small Business Projects at Social Networking Sites}

In respect with the support of small business projects, the following steps should be undertaken:

- It is essential to establish a commission for small business projects that is responsible for providing necessary consultancy, studies and information during the inception stages. Moreover, the commission is also responsible for the development of e-marketing methods through social networking sites and protects the rights of both investors and consumers.

- It is strongly recommended that electronic information bank must be established, which is helpful for assessing the accurate figures and statistics.

- To establish a fund that secures financing for small business projects.

\section{Method}

Descriptive methodology was used to illustrate the importance of e-marketing through social networking sites and its role in supporting small business projects. Analysis of data has been performed through SPSS. T-test, One-way Anova and Scheffe Test have been employed for identifying the significance of the collected data.

\subsection{Population}

The population was represented by the mangers of small business projects in Saudi Arabia. The population is specifically based on the managers who were extensively engaged in e-marketing via electronic social networking sites.

\subsection{Size and Type of Sample}

The sample was selected from the population of owners and managers of small business projects within the Kingdom of Saudi Arabia. Total 277 questionnaires have been distributed electronically but only 146 project's representatives have responded that only constituted $75 \%$ of the total sample.

\section{Results}

\subsection{Distribution of Sample'S Members by Sex}

Table 1. Distribution of sample's members per sex

\begin{tabular}{lll}
\hline Sex & Number & \% Percentage \\
\hline Male & 48 & 32.9 \\
Female & 98 & 67.1 \\
Total & 146 & $100 \%$ \\
\hline
\end{tabular}

The results depicted in Table 1 indicate that the total sample was comprised on 48 males and 95 females. 


\subsection{Distribution of Sample'S Members per Educational Qualification}

Table 2. Distribution of sample's members per educational qualification

\begin{tabular}{lll}
\hline Educational Qualification & Number & $\%$ Percentage \\
\hline Intermediate School Certificate \& below & 16 & 11 \\
Secondary School Certificate and Equivalent & 38 & 26 \\
University degree and above & 92 & 63 \\
\hline Total & 146 & $100 \%$ \\
\hline
\end{tabular}

Table 2 indicated that $63 \%$ of the sample respondents have university degree; whereas, $26 \%$ and $11 \%$ of the respondents have secondary school education and intermediate certificate.

\subsection{Correlation and Validity Analysis}

The correlation coefficient between the degree of each axis and the overall degree related to the role of e-marketing via social networking sites in regards of small business projects is mentioned in table 3 .

Table 3. Correlation coefficient

\begin{tabular}{ll}
\hline Axis & Correlation Coefficient \\
\hline The importance of e-marketing at social networking sites as perceived by the proprietors of the small & $0.866^{* *}$ \\
business projects. & \\
The level of application of e-marketing through social networking sites as perceived by the proprietors of & $0.795^{* *}$ \\
the small business projects. & \\
$\begin{array}{l}\text { Difficulties that confront marketing via electronic social networking sites (social media) and obstacles that } \\
\text { impede its success }\end{array}$ & $0.541^{* *}$ \\
\hline Note. $(* *)$ This sign indicated there is statistical significance at 0.01 levels. &
\end{tabular}

The result depicted in Table 3 signifies the range of correlation coefficient between $(0.541)$ and $(0.866)$. This implies that there is a high degree of internal consistency and a high degree of validity of the clauses (expressions) in the study questionnaire.

The correlation coefficients of clauses (expressions) of every axis, in relation to the overall degree of the axis are mentioned in Table 4.

Table 4. Correlation coefficient

\begin{tabular}{|c|c|c|c|c|c|}
\hline \multicolumn{2}{|c|}{$\begin{array}{l}\text { The importance of e-marketing at social } \\
\text { networking sites as perceived by the } \\
\text { proprietors of the small business projects }\end{array}$} & \multicolumn{2}{|c|}{$\begin{array}{l}\text { The level of application of e-marketing } \\
\text { through social networking sites as perceived } \\
\text { by the proprietors of the small business } \\
\text { projects }\end{array}$} & \multicolumn{2}{|c|}{$\begin{array}{l}\text { The difficulties that confront marketing } \\
\text { via electronic social networking sites } \\
\text { (social media) and the obstacles that } \\
\text { impede its success. }\end{array}$} \\
\hline Clause no. & $\begin{array}{l}\text { Correlation } \\
\text { Coefficient }\end{array}$ & Clause no. & $\begin{array}{l}\text { Correlation } \\
\text { Coefficient } \\
\end{array}$ & Clause no. & $\begin{array}{l}\text { Correlation } \\
\text { Coefficient } \\
\end{array}$ \\
\hline 1 & $0.845^{* *}$ & 2 & $0.716^{* *}$ & 13 & $0.497 * *$ \\
\hline 4 & $0.766^{* *}$ & 3 & $0.742 * *$ & 15 & $0.806 * *$ \\
\hline 5 & $0.811 * *$ & 6 & $0.509 * *$ & 21 & $0.689^{* *}$ \\
\hline 9 & $0.692 * *$ & 7 & $0.793 * *$ & 22 & $0.793^{* *}$ \\
\hline 10 & $0.839 * *$ & 14 & $0.725 * *$ & 24 & $0.645^{* *}$ \\
\hline 12 & $0.812 * *$ & 16 & $0.783^{* *}$ & 24 & $0.603^{* *}$ \\
\hline 18 & $0.756^{* *}$ & 17 & $0.806 * *$ & 26 & $0.779 * *$ \\
\hline 20 & $0.854^{* *}$ & 19 & $0.7016^{* *}$ & 27 & $0.876^{* *}$ \\
\hline 29 & $0.743 * *$ & 30 & $0.784 * *$ & 28 & $0.719^{* *}$ \\
\hline 31 & $0.679 * *$ & & & & \\
\hline 32 & $0.682 * *$ & & & & \\
\hline
\end{tabular}

Table 4 remarked that correlation coefficients of all clauses (expressions) have positively correlated with each other. Thus, it indicated that all clauses have good internal consistency with the representing axis. 


\subsection{Questionnaire Reliability}

The equation of Cronbach Alpha was opted to check the reliability of the questionnaire.

Table 5. Reliability of the questionnaire in relation to its various axes

\begin{tabular}{lll}
\hline Axis & No. of Clauses & Cronbach Alpha Coefficient \\
\hline $\begin{array}{l}\text { The importance of e-marketing at social networking sites as perceived by the } \\
\text { proprietors of the small business projects }\end{array}$ & 12 & 0.792 \\
$\begin{array}{l}\text { The level of application of e-marketing through social networking sites as perceived by } \\
\text { the proprietors of the small business projects }\end{array}$ & 10 & 0.845 \\
$\begin{array}{l}\text { The difficulties that confront marketing via electronic social networking sites (social } \\
\text { media) and the obstacles that impede its success. }\end{array}$ & 10 & 0.805 \\
Questionnaire in General & 32 & 0.860 \\
\hline
\end{tabular}

Table 5 showed the reliability coefficients generated by the equation of Cronbach Alpha.

The questions mentioned below are useful to analyze the results of the study.

First question: To what extent the significance of e-marketing via social networking sites at small business projects is recognized from the point of view of the sample's members?

Table 6 displayed arithmetic means, standard deviations, and the order of expressions pertaining to the importance of e-marketing through social networking sites (social media) at the small business projects from the viewpoint of the sample's members.

Table 6. Arithmetic mean and standard deviation

\begin{tabular}{|c|c|c|c|c|c|}
\hline Sr. & Expression & $\begin{array}{l}\text { Arithmetic } \\
\text { mean }\end{array}$ & $\begin{array}{l}\text { Standard } \\
\text { Deviation }\end{array}$ & Order & $\begin{array}{l}\text { Agreement } \\
\text { Degree }\end{array}$ \\
\hline 1 & $\begin{array}{l}\text { Advertisement and publicity via social networking sites have } \\
\text { become essential under the framework of the dominance of } \\
\text { technological advancement. }\end{array}$ & 4.59 & 0.802 & 1 & I fully agree \\
\hline 32 & $\begin{array}{l}\text { Marketing via electronic social networking sites achieves the } \\
\text { required benefits in the best manner. }\end{array}$ & 4.46 & 0.744 & 2 & I fully agree \\
\hline 9 & $\begin{array}{l}\text { The usage of e-marketing via social networking sites secures } \\
\text { chances for supporting, developing and expanding newly } \\
\text { beginning projects especially in future. }\end{array}$ & 4.40 & 0.801 & 3 & I fully agree \\
\hline 12 & $\begin{array}{l}\text { By practicing marketing via electronic social media sites, the } \\
\text { material fixed environmenthas transformed to a portable virtual } \\
\text { one, which is easily accessible to sites visitors at the internet all } \\
\text { over the world }\end{array}$ & 4.34 & 0.881 & 4 & I fully agree \\
\hline 10 & $\begin{array}{l}\text { I feel that e-marketing via social networking sites encourages a } \\
\text { number of male and female youth to establish their private } \\
\text { commercial projects and achieve self-sufficiency }\end{array}$ & 4.19 & 0.717 & 5 & I agree \\
\hline 5 & $\begin{array}{l}\text { The social networking sites assist in establishingwork relations } \\
\text { and in utilizing them in the exchange of advertisements with } \\
\text { proprietors of other projects }\end{array}$ & 4.17 & 0.764 & 6 & I agree \\
\hline 11 & $\begin{array}{l}\text { The social networking sites secure a modern e-market that helps } \\
\text { small business projects to economize in the expenditure of } \\
\text { marketing budget. }\end{array}$ & 4.14 & 0.664 & 7 & I agree \\
\hline 31 & $\begin{array}{l}\text { I feel that the new electronic marketing means have contributed } \\
\text { to reducing the challenges faced by small business projects }\end{array}$ & 3.86 & 0.724 & 8 & I agree \\
\hline 18 & $\begin{array}{l}\text { Marketing via the means ofsocial networking sites constitutes an } \\
\text { easy chance for accessing a wider range of the local market }\end{array}$ & 3.75 & 0.869 & 9 & I agree \\
\hline 29 & $\begin{array}{l}\text { I am of the opinion that e-marketing via forums and e-mail is } \\
\text { more successful than employingsocial networking sites. }\end{array}$ & 3.43 & 1.259 & 10 & I agree \\
\hline 4 & $\begin{array}{l}\text { Easy marketing via social networking sites coupled with their } \\
\text { less costhas affected the spread of small business projects. }\end{array}$ & 3.27 & 0.936 & 11 & I don't know \\
\hline 20 & $\begin{array}{l}\text { Marketing my project via the new electronic social networking } \\
\text { sites helped me to abolish the cost of sites, intermediaries and } \\
\text { distributors as well as other additional cost. }\end{array}$ & 1.75 & 0.953 & 12 & $\begin{array}{l}\text { I don't agree } \\
\text { absolutely }\end{array}$ \\
\hline \multicolumn{2}{|r|}{$\begin{array}{l}\text { The general arithmetic mean and agreement degree the significance of } \\
\text { e-marketingvia social networking sites at small business projects. }\end{array}$} & 3.86 & & I agree & \\
\hline
\end{tabular}


It is conspicuous from Table 6 that the arithmetic mean of expressions of the axis on the importance of e-marketing through social networking sites at small business projects were ranged in between of 3.86 to 4.59 .

Second question: To what extent is e-marketing effective in encouraging proprietors of small business projects and in maximizing the benefit of the spread of social networking sites?

To answer the second question of the study questions, 10 expressions were allocated for measuring the opinions of the respondents on the effectiveness of e-marketing in encouraging proprietors of small business projects and in maximizing the benefits of the spread of social networking sites. Following are the details of the results extracted from the answers of respondents:

Table 7. Arithmetic mean and standard deviation

\begin{tabular}{|c|c|c|c|c|c|}
\hline No. & Expression & Mean & $\begin{array}{l}\text { Standard } \\
\text { Deviation }\end{array}$ & Order & $\begin{array}{l}\text { Agreement } \\
\text { Degree }\end{array}$ \\
\hline 19 & $\begin{array}{l}\text { I totally depend in marketing via social networking sites on the } \\
\text { great number ofthose who frequently visit these sites. }\end{array}$ & 4.55 & 0.814 & 1 & I fully agree \\
\hline 8 & $\begin{array}{l}\text { I benefit from the numerous marketing services provided by the } \\
\text { internet compared to traditional marketing services (ones). }\end{array}$ & 4.44 & 0.761 & 2 & I fully agree \\
\hline 30 & $\begin{array}{l}\text { I set certain hours of the dayfor communicating with the customers } \\
\text { at social networking sites. }\end{array}$ & 4.38 & 0.873 & 3 & I fully agree \\
\hline 17 & $\begin{array}{l}\text { I know the performance ofmy project through the transparency of } \\
\text { dealing with customers in the networking sites and respond to their } \\
\text { direct reaction. }\end{array}$ & 4.25 & 0.801 & 4 & I fully agree \\
\hline 2 & $\begin{array}{l}\text { I use e-marketing through the social networking sites to ensure } \\
\text { direct access to customers and to identify consumers' preferences }\end{array}$ & 4.10 & 0.785 & 5 & I agree \\
\hline 16 & $\begin{array}{l}\text { I exercise the marketing function viaelectronic means other than } \\
\text { those of social networking sites }\end{array}$ & 4.02 & 4.02 & 6 & I agree \\
\hline 3 & $\begin{array}{l}\text { I attempt to be available at social networking sitesto inform my } \\
\text { clients about what is new pertaining to my new products and } \\
\text { services and to expand the customers' base. }\end{array}$ & 3.97 & 0.834 & 7 & I agree \\
\hline 6 & $\begin{array}{l}\text { My constant presence at the electronic social networking sites } \\
\text { contributed to conveyingmy marketing message to a very large } \\
\text { number of customers. }\end{array}$ & 3.83 & 0.882 & 8 & I agree \\
\hline 7 & $\begin{array}{l}\text { My appearance atthe electronic social networking sites helped me to } \\
\text { know more about mycommercialproject. }\end{array}$ & 3.79 & 0.798 & 9 & I agree \\
\hline 14 & $\begin{array}{l}\text { The electronic social networking sites assistedme in supporting my } \\
\text { commercialprojectvia taking advantage of the recommendations of } \\
\text { mycurrent clients and their positive experience in dealing with me }\end{array}$ & 2.46 & 0.655 & 10 & I don't agree \\
\hline \multicolumn{2}{|r|}{$\begin{array}{l}\text { The general arithmetic mean and agreement degree for theeffectiveness of } \\
\text { e-marketing in encouraging proprietors of small business projects and in } \\
\text { maximizing the benefitof the spread ofsocial networking sites }\end{array}$} & .3 .98 & & I agree & \\
\hline
\end{tabular}

Results from Table 7 have indicated the arithmetic mean of expressions of the axis on the effectiveness of e-marketing in encouraging proprietors of small business projects were ranged in between of 2.46 - 4.55.

Third question: What are the difficulties that confront the proprietors of small business projects when they practice electronic marketing via social networking sites, and that constitute obstacles that hinder the success of these projects?

In order to answer the third question, 10 expressions were allocated for measuring the opinions of the sample's members on the difficulties that confront by the proprietors of small business projects. Proprietors when practice electronic marketing via social networking sites and the obstacles constituted to them, hinder the success of these projects. Following are the details of the results extracted from the answers of the respondents: 
Table 8. Arithmetic mean and standard deviation

\begin{tabular}{|c|c|c|c|c|c|}
\hline No. & Expression & Mean & $\begin{array}{l}\text { Standard } \\
\text { Deviation }\end{array}$ & Order & $\begin{array}{l}\text { Agreement } \\
\text { Degree }\end{array}$ \\
\hline 13 & $\begin{array}{l}\text { The small business projects face the difficulty of attracting } \\
\text { customers and gaining their confidence trust, but this } \\
\text { difficulty, which constitute an obstacle impeding the success } \\
\text { of these projects, can be overcome via engagement in social } \\
\text { networking sites. }\end{array}$ & 4.06 & 0.707 & 1 & $\begin{array}{l}1 \text { absolutely } \\
\text { don't agree }\end{array}$ \\
\hline 15 & $\begin{array}{l}\text { I feel more comfortable in traditional dealing with clients and } \\
\text { keeping away as much as possible from electronic dealings } \\
\text { through social networking sites. }\end{array}$ & 3.38 & 1.032 & 2 & I am neutral \\
\hline 27 & $\begin{array}{l}\text { I encounter difficulty in marketing via the electronic social } \\
\text { networking sites. }\end{array}$ & 3.03 & 0.774 & 3 & I am neutral \\
\hline 21 & $\begin{array}{l}\text { I confront the problem of low confidenceand lack of } \\
\text { persuasion on the part of the customer he exercises purchasing } \\
\text { through social networking }\end{array}$ & 2.50 & 0.912 & 4 & 1 don't agree \\
\hline 23 & $\begin{array}{l}\text { The Internet infrastructure in the Kingdom of Saudi Arabia } \\
\text { andtheir weak ability impedes the easy achievement of the } \\
\text { project task. }\end{array}$ & 2.42 & 0.821 & 5 & 1 agree \\
\hline 25 & $\begin{array}{l}\text { The high rates demanded by internet service providers in the } \\
\text { Kingdom of Saudi Arabia affect the users of the electronic } \\
\text { social networking sites. }\end{array}$ & 1.80 & 1.154 & 6 & 1 don't agree \\
\hline 28 & $\begin{array}{l}\text { The lack of the two factors of security and confidentiality } \\
\text { makes me more cautious in commercial dealing via social } \\
\text { networking sites. }\end{array}$ & 1.79 & 0.804 & 7 & $\begin{array}{l}1 \text { absolutely } \\
\text { don't agree }\end{array}$ \\
\hline 24 & $\begin{array}{l}\text { The ineffectiveness of legal and judicial procedures pertaining } \\
\text { to the electronic commercial transactions raises my concern } \\
\text { on the protection of moral and material rights. }\end{array}$ & 1.68 & 1.081 & 8 & $\begin{array}{l}1 \text { absolutely } \\
\text { don't agree }\end{array}$ \\
\hline 22 & $\begin{array}{l}\text { I face a difficulty regarding the inefficiency of laws and rules } \\
\text { that regulate the ions to protection of the special rights } \\
\text { pertaining to for my products and services and their } \\
\text { preservation from due imitation or theft. }\end{array}$ & 1.56 & 1.010 & 9 & $\begin{array}{l}1 \text { absolutely } \\
\text { don't agree }\end{array}$ \\
\hline 26 & $\begin{array}{l}\text { The fear of customers of using credit cards and the lack of } \\
\text { development regarding the electronic payment systems may } \\
\text { cause certain selling transactions of the business project to be } \\
\text { blocked. }\end{array}$ & 1.51 & 0.956 & 10 & $\begin{array}{l}1 \text { absolutely } \\
\text { don't agree }\end{array}$ \\
\hline \multicolumn{2}{|r|}{$\begin{array}{l}\text { The general arithmetic mean and agreement degree for the } \\
\text { difficulties that face the small business proprietors when they } \\
\text { practice e-marketing through social networking sites; and that } \\
\text { constitute obstacles impeding the success of these projects. }\end{array}$} & $2: 38$ & & \multicolumn{2}{|c|}{1 don't agree } \\
\hline
\end{tabular}

The results of Table 8 have indicated the arithmetic mean of expressions of the axis on the difficulties that are faced by the small business proprietors when they practice e-marketing through social networking sites were ranged between 1.51 and 4.06 .

\section{Discussion}

Majority of the managers and promoters of small business projects at the social networking sites were females with percentage more than $67 \%$; whereas, the percentage of males were only $32 \%$. Furthermore, majority of the small business projects, which market their products and services via the social networking sites, were managed by individuals. These individuals hold higher university degrees and constitute $63 \%$ of the sample. It is indicated that highly academically qualified Saudis market their products through social networking sites and simultaneously achieve self-sufficiency. With respect to the effectiveness of e-marketing and the level of its application at the electronic social networks sites, a large proportion of the respondents indicated their agreement on the expression that they totally depended on marketing via social networking sites. Moreover, the most prominent difficulties faced by the small business projects were represented in the attraction of clients and gaining their confidence. The proprietors and managers who want to market their products via social networking sites must prepare required preliminary feasibility studies that provide the useful guidelines for the implementation of these activities. Innovation in the quality of small business projects must be taken into account and that concentration must be made on the basic characteristics of the products and services. At conclusion, exhibitions must be conducted and support specialized electronic sites and blogs that must be provided for the due promotion of the products and services of small business projects. It is strongly recommended that in future, the role of e-marketing must be assessed by using cross-cultural comparison in 
different countries. Moreover, the role of social networking sites and e-marketing must be evaluated in different parts of the world. The research was limited to some small business projects. As a recommendation, future studies must be conducted to identify the impact of e-marketing in large and medium sized companies.

\section{Acknowledgements}

The author is very thankful to all the associated personnel in any reference that contributed in/for the purpose of this research. Further, this research holds no conflict of interest and is not funded through any source.

\section{References}

Abu, R. I. (2006). Challenges facing small business Projects. Oman, Jordan: MOASAST IRADAH .

Ali, A. A. (2007). Trends of Internet Users of Internet Users in the Kingdom of Saudi Arabia towards Electronic Marketing. Kingdom of Saudi Arabia.

Al-Sharman \& Al-Bawana. (2011). Impact of E-marketing as an Excellence Tool in Industrial Business Organizations, Jordan.

Al-Sharman, Z. M., \& Albwaanh, M. S. (2011). The Impact of E-marketing as a Distinction Tool at the Industrial Business Organizations. Amman, Zarqa University College - Balqa Applied University, Jordan.

Altai, Y. H. A., \& Hashim, F. (2009). E-marketing. Amman: Awwarraq House for Publication and Distribution.

Assiri, B. (2004). Small and Medium Business Projects in the Arab world: Problems and Development Horizons prospects. Manama: Bahrain University.

Bear, J. (2013). The Power of Now (Connections 2013 the power of one). USA, New York.

Cao, Y. (2013). Marketing in Social Media: Why do Companies Need to construct and Implement Social Media Marketing Strategy. Michigan: Gerhad Havvrank.

Ghali, P. (2012). Social Media Marketing. New York: Contract Group Company.

Grahl, T. (2013). The 6 Types of social media. Virginia, USA: Out think group.

Kelly, L., Kerr, G., \& Dernnan, J. (2010). Avoidance of Advertising in Social Networking Sites: The Teenage Perspective. Florida: American Academy of Advertising.

Kyle, L. (2010). Twitter marketing for dummies (1st ed.). Indiana, USA: Wiley.

Maisa, K. (2003). E-commerce with the Framework of Digital Economies-Free Business and Significance of E-marketing (An Analytical Study Derived from the Actual Situation of The Organizations of the Saudi Businesses at the Private Sector). Kingdom of Saudi Arabia.

Member, I. (2013). Advertising in Social Media. Scientific Journal of Pure and Applied Science, 5, 222.

Welson, J., Guinan, P. J., Parise, S., \& Weinberg, B. (2011). What's Your Social Media Strategy? Boston: Harvard Business.

Yousuf, A. F. (2006). Internet Applications in Small Business Projects (An Introduction to Qualification towards Excellence).

\section{Copyrights}

Copyright for this article is retained by the author, with first publication rights granted to the journal.

This is an open-access article distributed under the terms and conditions of the Creative Commons Attribution license (http://creativecommons.org/licenses/by/4.0/). 